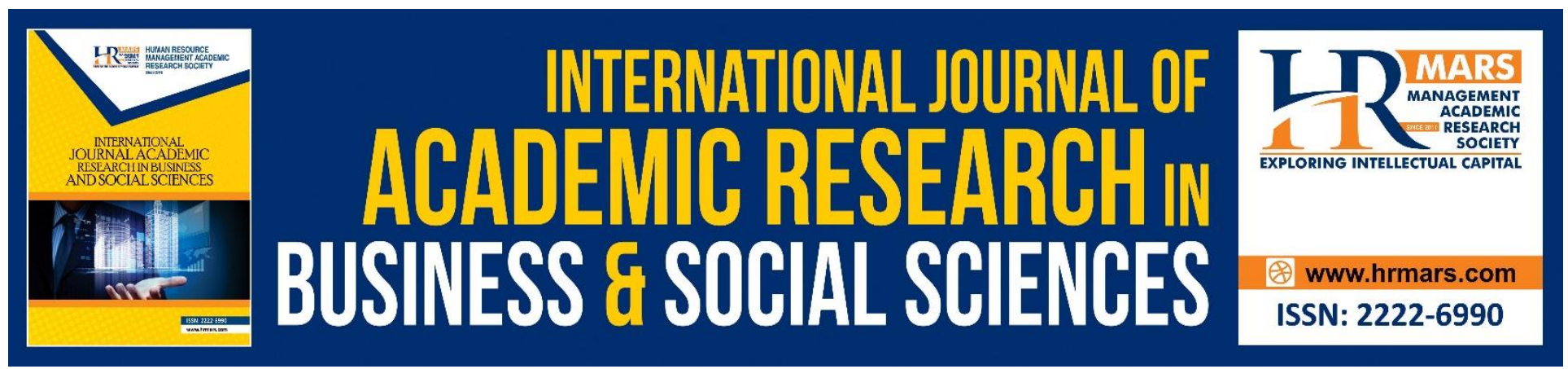

\title{
Integrated Model and Study on the Prominence of Social Entrepreneurship
}

\author{
Md. Abu Naim Shorkar, Wang Hong
}

To Link this Article: http://dx.doi.org/10.6007/IJARBSS/v8-i11/4894

DOI: $10.6007 /$ IJARBSS/v8-i11/4894

Received: 08 Oct 2018, Revised: 23 Oct 2018, Accepted: 29 Oct 2018

Published Online: 24 Nov 2018

In-Text Citation: (Shorkar \& Hong, 2018)

To Cite this Article: Shorkar, M. A. N., \& Hong, W. (2018). Integrated Model and Study on the Prominence of Social Entrepreneurship. International Journal of Academic Research in Business and Social Sciences, 8(11), 181-197.

\section{Copyright: (C) 2018 The Author(s)}

Published by Human Resource Management Academic Research Society (www.hrmars.com)

This article is published under the Creative Commons Attribution (CC BY 4.0) license. Anyone may reproduce, distribute, translate and create derivative works of this article (for both commercial and non-commercial purposes), subject to full attribution to the original publication and authors. The full terms of this license may be seen

at: http://creativecommons.org/licences/by/4.0/legalcode

Vol. 8, No. 11, 2018, Pg. 181 - 197

Full Terms \& Conditions of access and use can be found at http://hrmars.com/index.php/pages/detail/publication-ethics 


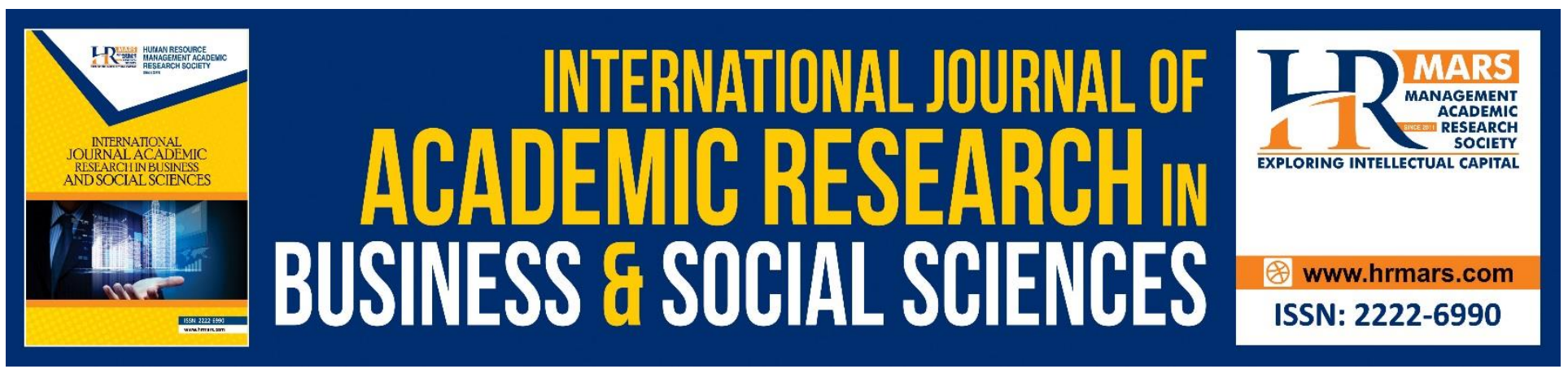

\title{
Integrated Model and Study on the Prominence of Social Entrepreneurship
}

\author{
Md. Abu Naim Shorkar \\ School of Economics, Shanghai University, Shanghai, China \\ Email:nshorkarbd@gmail.com
}

Wang Hong

Associate Professor, School of Economics, Shanghai University, Shanghai, China

Email: 13901601536@163.com

\begin{abstract}
Social entrepreneurship is an activity with an embedded social purpose, has been on the ascendancy in recent decades. A partial index of this surge is revealed by the increase in the number of nonprofit organizations. The key focus for social entrepreneurship is addressing the social problem and taking action to eliminate this problem from society. This article analyzes the impact of social concern with a new wing of the general business model which will include CSR and Social entrepreneurship. Organizations can deliver social goods with business acumen by this model and we can ensure employment, poverty reduction, and attain a balance within our community. We find that social business brings the competitive advantage on CSR to achieve long-run social balance in our society, and a new business model will deliver more impact rather than existing giving system. The social business scenario in Bangladesh can also contribute to fulfilling of the social demand and secure work and property reduction in the long run.
\end{abstract}

Keywords: Social Entrepreneurship, Entrepreneurship, Corporate Social Responsibilities, Social Business, Muhammad Yunus, Grameen, Bangladesh

\section{INTRODUCTION}

Social entrepreneurship is an activity with an embedded social purpose, has been on the ascendancy in recent decades. Social business, with its focus on innovative leadership, in leadership which can change in the field of the traditional commercial enterprise. In countries where national government lack of the resources to meet the societal needs of their populations, social entrepreneurs can develop innovative ways of providing access to the disadvantaged groups of masses. Social 
entrepreneurship is made reference to the case of applying business knowledge and skills of market in the nonprofit sector, namely when nonprofit enterprise develops innovative way to earn income (Reis, 1999; Thompson, 2002). Social entrepreneurship is seen by these governments as having the potential to renew interest in community action and non-formal education to solve local problems in increasing complex and rapidly changing societies (Danaher, Moriarity, \& Danaher, 2003; Oyanagi, 2003). This requirement applies not merely to the start-up phase of an enterprise, but also throughout its life cycle. Historically, non-profit organizations have had a long practice of earning income (Zimmerman and Dart, 2000), examples of such include recycled material clothing shops and second-hand gift shops. In the narrowest sense, under entrepreneurship is meant a management scheme founded on innovation and risk, whose aim is to obtain entrepreneurial goals.

In a wide sense, social entrepreneurship is defined as a specific component of public reproduction that provides the necessary dynamics in the reproduction process, more efficient combinations of factors of production, labor, capital, ideas, data, and business webs to be enforced in all areas of foods, education, and health and so on, irrespective of the scale of the action. In ordination to be a social entrepreneurial enterprise, it has to create something fresh and dissimilar from the existing one, to organize itself in a different, more productive manner. The activity of Grameen-Danone Foods Ltd, BRAC, Grameen Intel, Grameen Veolia Water Limited, etc., is a typical example of social entrepreneurship in Bangladesh. The social entrepreneur is who use their own ideas and actions to puzzle out our social problem. They are not just getting a profit also they are resolving some other problem around our society, end of the day they are doing for the community as the return they also are drawing benefits for himself.

\section{LITERATURE REVIEW}

Social entrepreneurs drive social innovation and translation in diverse areas including education, wellness, environment and enterprise growth. According to Thompson, Alvy and Lees (2000:328), the examples are used from Britain are to influence their definition of social entrepreneurs as "people who realize where there is an opportunity to fulfill some unmet demand that the state welfare system will not or cannot play, and who collect together the necessary resources (broadly speaking people, often volunteers, money and premises) and utilize these to "make a difference'". Philosophically, social business is founded on what Prof. Dr. Mohammad Yunus identifies as the two basic motives of human beings, selfishness, and selflessness. Selfishly, people do seek profit through business; nevertheless, social business is similarly based on the latter motive people by performing philanthropic services, like establishing community centers, public parks, health clinics, art museums, mosques and churches. Canada's BC Centre for Social Enterprise (2015) acknowledges that on the widest basis, a social enterprise is a revenue-generating business with two goals: one that deals with achieving social outcomes, be it ethnic, community economic or environment, and the other goal is to earn revenue; Social Enterprise UK (2017) defines social enterprise as 'businesses that trade to tackle societal problems, improve communities, people's life chances or the environment'.

In this article seeks to hash out the overview of the idea, the current practice of CSR and Social business in Bangladesh, authors integrated the existing general business model with a social business model to avail more progressive impact on our company. According to Yunus, "In the present-day 
economic system, CSR would run up against a basic problem - managers' legal obligation to their stockholders to maximize net income unless they mandate otherwise. They cause to design the company to pursue profit first and then add the social features - provided that the social features don't interfere with maximizing net income". As aforesaid discussion, general entrepreneurship refers to taking a lead to open up a new venture or diversification of the existing line of work, while social entrepreneurship principal center of attention on producing social capital without earning measurement. Author defined social entrepreneurship as a, community based product development to identify social need to conform to the social development goal along with a financial return for the business extension to contribute for the next generation. Subsequently all, entrepreneurs need capital to hold along with the process and get a positive change in the society.

\section{METHODOLOGY OF THE STUDY}

Data and Information: This article is based on data gathered from several secondary sources, including books on social business authored by Dr. Muhammad Yunus, different articles on social business, business ethics and societal responsibility, and a few related websites.

Explanatory Structure: The analysis will be principally based on the description and we build up a new integrated business model, so statistical and econometric analyses are not feasible options due to the fact that, we haven't applied our new integrated business model to the real business practice. That's why impacted data are not available for this new concept.

\section{PURPOSE OF THE STUDY}

The primary aim of the study is to furnish the conceptual presentation with a new integrated model for the development of Social Entrepreneurship at the same time while the person/organizations doing CSR practice within the traditional business to be more focus on social grounds. The specific aims of the study are included, A. To distinguish the basic theme, model, and principles of social entrepreneurship approach; B. To compare the Social Entrepreneurship with CSR, considering traditional business practice; $C$. To push our idea is to include social entrepreneurship business in traditional business considering CSR of a greater contribution to society. In a further aspect, entrepreneurship has been the fundamental engine of the ontogeny of the business sector as well as a driving force behind the rapid expansion of the social sector. This article shows that analysis of social entrepreneurship and a new commercial enterprise model, including Corporate Social Responsibility and Social Business and the analysis also highlights the impact of social entrepreneurship and presents a framework on how to approach the social entrepreneurial process more consistently and effectively with respect to the corporate social obligation.

\section{CORPORATE SOCIAL RESPONSIBILITY}

In the modern business dynamics, corporate social responsibility is identified with corporate behavior, corporate reputation and business ethics must be set as the ethics of reason, as social responsibility, which takes place as a dialogue between countries, oriented towards a common goal. For managers, the implementation of specific initiatives in the field of corporate ethics means social responsibility. Corporate social responsibility is relatively new phenomenon practicing in business conduct and business relationships in Bangladesh, with its significant emphasis on ethics, this concept 
INTERNATIONAL JOURNAL OF ACADEMIC RESEARCH IN BUSINESS AND SOCIAL SCIENCES Vol. 8, No. 11, Nov, 2018, E-ISSN: 2222-6990 @ 2018 HRMARS

embraces and embraces the idea of future generations and guarantees sustainable development. Carrol (1991) defined corporate social responsibility (CSR) as "an organization's commitment to operate in an economically and environmentally sustainable manner while recognizing the interests of all its stakeholders".

As opposed to, Azim, Ahmed, and D'Netto (2011) stated, CSR is not a moral hesitation that financial institutions face in an environment of anomalous corporate exercise. These organizations are as well concerned with the assurance of sustainable progress. Therefore, to understand the essence of social responsibility and the ethics of business is to assume that they change with time and with the change in circumstances. Managers should be aware of their own responsibilities for introducing acceptable ethical standards into their organizations. Corporate social responsibility, in general, is expressed both in the care of the company's employees and in the commitment to the ecology and community issues in which the company operates. The behavior of organizations can be conditionally differentiated into four main "upward" categories or levels, depending on the extent of social responses: (1) Economic responsibility - measured in financial performance indicators, (2) Legal responsibility - is to comply with laws, rules, and regulations, (3) Ethical responsibility - relates to compliance with rules and standards of conduct, (4) Philanthropic responsibility - it is entirely voluntary and closest to concept of social responsibility. However, CSR doesn't contribute to guild for long run solution of social demand, similar social business does, in certain level CSR contributing to the nation, mostly based on sudden need, evidently they do after protecting organizational goal, sometimes, different company used it as a promotional instrument of their company, they push this into social media and newspaper, whereas, social entrepreneurs keep engaging themselves to obtain a social demand for further development of social business with respect to law and ethical responsibilities.

\section{SOCIAL BUSINESS}

Social entrepreneurship is all about realizing the social complication and unravel it and attain a social alteration by applying entrepreneurial operations, processes with ethics. Nobel Peace Prize (2006), Presidential Medal of Freedom (2009) and Congressional Gold Medal (2010) Winner, Prof. Muhammad Yunus, is a Bangladeshi Social Entrepreneur. He said "... if we want to be real human being, there should be at least two businesses. One business to make money to satisfy our selfish part of it and there should be another part another business to express our self-less part, I am calling it social business, so second business is to make an impact in world, make a difference in the life of the people, that's the social business, it's a non-loss and non-dividend company. I do that I get into that business not for making any personal benefit out of it, I want to make a difference in a person's life, and I want to solve the problem around me, that's why I did the social business. There could be two business profit-making business and social business at the same time ..." unlike a non-profit, a social business is not dependent on donations or on individual or public endowment to subsist and to utilize, like, other organizations, it's a self-sustainable. Furthermore, unlike a non-profit, where funds are spent only once on the field, funds in a social business are invested to increase and improve the business' operations in the field on an indefinite basis. Per Yunus' quote: "A charity dollar has only one life; a social business dollar can be invested over and over again." In his book "Banker to the Poor; Micro-Lending and the Battle against World Poverty' Muhammad Yunus said "If you go out into 
the real world, you cannot miss seeing that the poor are poor not because they are unreasonable or illiterate, they cannot keep their labor income. They hold no command over capital, and it is the ability to control capital that gives people the power to spring up out of poorness". This quote by perhaps one of the greatest socially responsible entrepreneurs of all time is exactly the insight we need into the minds of entrepreneurs of corporate social responsibility, he not only identifies a very real problem in the world but he also initiated to provides a solution, like, Grameen GC Eye Care Hospital, Grameen BASF, Grameen Bank etc., and BRAC and SME Foundation also is a great example of Social Business in Bangladesh.

Social business has a heavy impact on continuing development of our society, this is the only path which can make positive change in the earth by fulfilling's social need and making profit also, it's a concern for social cause, and mostly it's not just giving like CSR. Hither, the entrepreneur also can gain money for his living from salary, end of the day entrepreneur also have to fix his/her everyday life. But social business is a capital idea to cut poverty and make people self-depended being an entrepreneur or running for the company related to social need. Altogether, I want to say, social business is a feeling only those people who is interested who want to do something for making change and contribute to earth, this business is not for money making people, who only after money, who don't have any intention to bestow for the country, but those people will get involved who want to be commemorated for his/her work by solving actual problems from our country.

\section{SOCIAL ENTREPRENEURSHIP}

Social business indicates to innovative activity with a social purpose in either for the profit, with social intended commercial ventures (e.g., Dees \& Anderson, 2003; Emerson \& Twersky, 1996) or in the root of social entrepreneurship, the fellowship and other entrepreneurship are implementing strategy solutions, development fund, and solution of social culture or environmental events. Incorporate social entrepreneurship (e.g., Austin, Leonard, Reficco, \& Wei-Skillern, 2004); Traditional entrepreneurs typically measure business performance based on financial calculation, revenues, and promotion, but social entrepreneurs or non-profit organizations are assessed by achieving their goal of positive "return to society" and contribute to the resolution of social movement.

Social entrepreneurship typically attempts to further broad social, ethnic, and environmental goals often associated with the voluntary sector. An individual who makes an enterprise with the intention of resolving social problems or effecting social change. Social business was defined by Nobel Peace Prize Winner Professor Muhammad Yunus and is distinguished in his books (Banker to the Poor, 1999), a social concern as a business: Created and designed to address a social problem or in the nonprofit sector, or across sectors, such as hybrid structural forms which mix for-profit and nonprofit approaches (Dees, 1998). Social entrepreneurship means the new development of the business sector, the efficient use of resources, creating the basis for further development of the enterprise. A social entrepreneur is a person who not only possesses the necessary knowledge, skills and personal qualities but also initiates and develops entrepreneurial activity as a collaborator, not as just an owner. 


\section{A. SOCIAL ENTREPRENEURSHIP STRATEGIES}

The strategy is one of the leading keys in any business, strategic planning is an activity to assess the current situation and to position the entity in the changing circumstances in the future. Strategic innovation and high technology are a factor that increases the likelihood of market success. It is a comprehensive designed to deliver the mission of the enterprise and achieve its ultimate goals. To achieve entrepreneurship goal we have to focus on following strategies; Market development, Product development, and Innovation. Market development is known for various strategies for the product that pursue opportunities and match the strengths of entrepreneurial activity, Product development is considered as a key point as related to product or company growth, we have to be updated with time and from competitors, and Innovations include new ideas, experiments, and new trends. In social business, innovation means sustainable and rapid growth. For the consumer, innovation means high quality and more useful goods, more efficient services and a high standard combination.

\section{B. SOCIAL ENTREPRENEURSHIP FINANCING}

When starting a new business, along with the marketing, production and organizational plan, it is necessary to develop a strategic financial plan, which determines the number of necessary investments and working capital, the sources and the cost of capital, as well as the movement of financial resources over time. The financial plan itself consists of an entity's draft balance sheet, a revenue and expenditure account, and a plan for the sources and distribution of financial resources. The total capital requirement for business start-up includes three major components - key capital, reduced capital and settlement cost. However, there are four main ways to provide business funds: Self-investment, Taking credit, persuading others to invest, and getting help. After having fund need to be more professional on using of the money, business growth and return depend on four W question, whom, what, where and when you are investing, so before using the money, you need to judge yourself based on your strength and weakness to set up own business.

\section{PRODUCT LIFE CYCLE}

The Product lifecycle covers the time and process from its creation to the implementation of its strategic plans, every product has a life cycle, if we don't update on time, then the product may decline. Product Life Cycle Theory is an economic theory that was developed by Raymond Vernon in response to the failure of the Heckscher-Ohlin model to explain the observed pattern of international trade. Product life-cycle theory first published in 1966, in turn, influenced the behavior of companies, Raymond Vernon published an article, "International Investment and International Trade in the Product Cycle". International product life cycle, or the general product life cycle which was manifested in 1966 by the economist Raymond Vernon, is still an extensively used model in economics and marketing. The products, enter the market and disappear gradually. Raymond Vernon says, each product has a certain life cycle that starts with its development and conclusions with its fall. There are four stages of a product's lifecycle: introduction, growth, maturity, and decline. The length of a product life cycle stage varies for different wares, one stage 
INTERNATIONAL JOURNAL OF ACADEMIC RESEARCH IN BUSINESS AND SOCIAL SCIENCES Vol. 8, No. 11, Nov, 2018, E-ISSN: 2222-6990 @ 2018 HRMARS

may live some weeks while others even last decades. This evidences that the product life cycle is really alike to the diffusion of innovation model that was developed in 1976 by Everett Rogers.

We can utilize this model into social enterprise (Product/Services), to secure the product for social concern. Other than business may decline as per this model, because always competitors want to attain competitive advantage in any business. The theoretical model shows that in the first phase the company introduce product into market, and create consumer awareness and boosting demand second phase growth of market of specific product, its start just after successful launch on first phase, third phase, it's time to become mature and to act as market leader, but there are several competitors by this stage and the original provider may reduce prices to sustain market share and support sales. Profit margins may decrease, but the business remains attractive because demand and price, and same time for further product development and promotion, sometimes, there is another new phase is neither increase nor decrease in the volume of sale, may need modification in the attribute of the product is needed to attract new consumers, and last in the list, sometimes every product has to face falling situation, even this may occur when the product peaks in the maturity stage and then begins a downward slide in sales, because of competitors or no further research on development, so always have to keep in mind our product for any business in even in social business can also be decline, so always we have to be updated with market demand, aware of competitors and research on new product development.

\section{SOCIAL ENTREPRENEURSHIP IMPACT IN BANGLADESH}

Bangladesh is the world's ninth most populous country, with a population of 169 million. It is a lower middle-income nation with lower literacy and more than $30 \%$ of the population living under the poverty line of $\$ 1.25 /$ day (World Bank, 2014). It suffers, nevertheless, maintained an impressive course record of growth in recent years with gross domestic product (GDP) growth exceeding 6\% 2013-2015. In spite of persistent wealth inequality, is reckoned to reach a middle - income status by 2021 (World Bank, 2014). Social enterprise activity in Bangladesh is developing. As per State of Social Enterprise Survey 2015, by the British Council is the UK's international organization in Bangladesh. They surveyed 149 social enterprises and they found the following information: Average last six years' operations, they found most of the entrepreneurs are under 35 years, and statistics show that it has been increased by the number of full-time job placement increased from 3,163 to 3,291, and parttime job increased from 3,183 to 3388 .

In the result of growth plan by investment highest $85 \%$ and lowest $61 \%$ for new development of new product and services, so still we have come up with new ideas, and in case of barriers, highest $36 \%$ of technical shortage and whereas lowest $24 \%$ is for lack of access and support. On 25-26 February 2015, they organized the first ever high-level policy dialogue called Social Enterprise: Policy and Practice (In the Landscape for Impact Investing in South Asia), in partnership with Swiss Agency for Development and Cooperation (SDC). More than 100 policy experts, social entrepreneurs, academics and social investors from South Asia, East Asia, and the UK to know how to create a good policy environment for social enterprises in Bangladesh. 
INTERNATIONAL JOURNAL OF ACADEMIC RESEARCH IN BUSINESS AND SOCIAL SCIENCES Vol. 8, No. 11, Nov, 2018, E-ISSN: 2222-6990 @ 2018 HRMARS

\section{INTEGRATED BUSINESS MODEL}

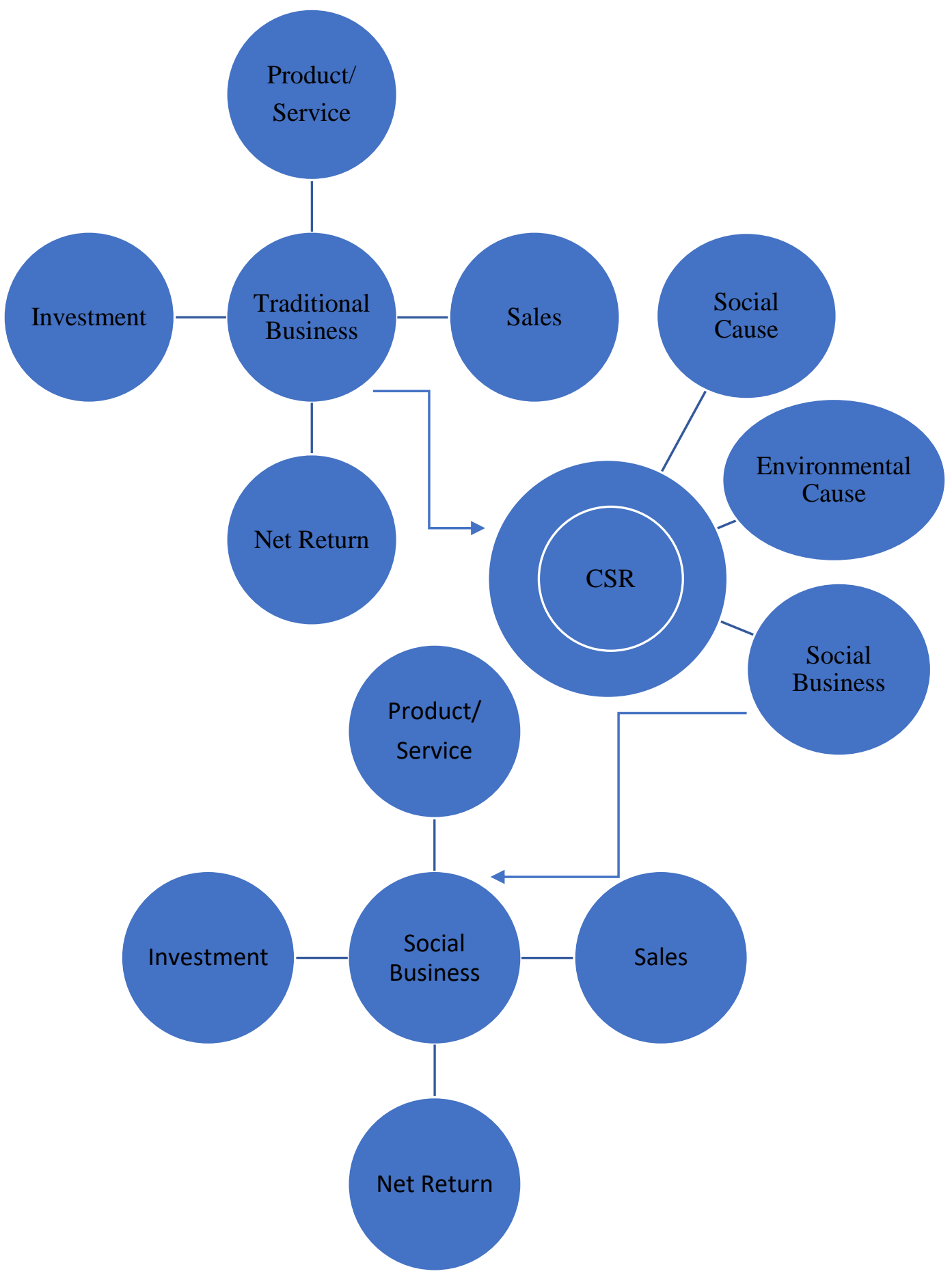

Figure 1: Integrated Business Model 
INTERNATIONAL JOURNAL OF ACADEMIC RESEARCH IN BUSINESS AND SOCIAL SCIENCES

Vol. 8, No. 11, Nov, 2018, E-ISSN: 2222-6990 @ 2018 HRMARS

In this integrated business model, author combined traditional and social business so that society can get a more competitive advantage at the same time with respect to corporate social responsibility. To explain this model, we separated it into three section, A, B, and C.

\section{SECTION A - TRADITIONAL BUSINESS}

In traditional Business or just profit-making concern, concern with a financial return to maximize earnings and generally its focuses on, Investment, Product/Service, Sales and Net Return. The author extends it to the CSR.

\section{SECTION B - CSR}

Author included CSR as a key focus point for every traditional business, mandatorily companies should contribute for social development for greater interest of our society, always we should not depend on somebody else do, or it is an only duty of government, these ideologies not existed now, we have to stand with government, and together we can achieve more for next generations, although CSR is just a giving something to society, organization/person contributing for a specific reason or any special cause, like, natural disaster, winter cloth for unprivileged living peoples etc., mostly CSR focus on Social cause and environmental cause. Here author extended it into Social Business for long-run development along with individuals, society, and environment. However, it doesn't mean CSR won't exist, general CSR activity will be continuing and others aspect will remain same with respect to CSR activity, but there will be a special hub for social business for a long-term solution in under one business model.

\section{SECTION C - SOCIAL BUSINESS}

Nowadays, everyone is talking about social business, here author brings an extension of social business from CSR, and point a new platform for social cause of continuous development, here also focus on the following steps: Investment, Product/Service, Sales and Net Return. But here investment is focused on solution of social problems, then, make some product/service which is related to social development, it could be health sector, teaching, food etc., then, sales, then social enterprises will sell all product/services with minimum earnings, so that everyone can enjoy the benefit of social product/services, last in the list, net return, here after the salary of staffs, and after return on investment, rest of profit money will be re-invested in existing social project or open another new project for continuous social development. After aforesaid discussion, this business model covers traditional, social and CSR aspects for overall development of whatever country. Authors included CSR with Social Business, because most of the time CSR is just giving something to society, mostly organization/person giving for a reason in one time for any special case, example, climate effect, food, dress, medical services, and others help as needed, but in case Social Business we can help our society for a many reasons and same time we can expand our business to large group of people for continuous development, example, Community Shop (UK), Bio Lite and Cloud Factory etc. Authors want to include Social Business in any sort of traditional 
commercial enterprise under the shadow of CSR activity for every organization, but it doesn't mean CSR won't be exiting, general CSR activity will be going forward and other aspect will remain same and with respect to CSR activity, there will be a special hub for social business for long term evolution and solutions of our societal and environmental challenges. Like, Grameen, Danone, NIKA etc., is contributing to society by social concern.

As social business is a relatively new phenomenon, then those individuals or company, who are contributing to society by doing CSR activities mostly for once in a year or any special cause, whatever money they want to contribute under shadow the of CSR, by this money they can open a hub of social business, from this business, whatever money they will earn organizations/individuals will contribute to society and it will continue year after years, so, my approach is to them why don't everyone start an integrated business, as this model, include traditional commercial enterprise, CSR and social business together to earn money and same time contributing to our nation for greater interest of living life and to create a perfect place to living for our next generations. We can contribute to society in many ways, but especially following ways: Making some goodies for regular social needs, opening job opportunities; even for villagers, contributing profit for social and environmental reasons, carrying on business growth for next generations and expanding different product line with welfare.

\section{SOCIAL RESPONSIBILITY OF BUSINESS}

Social Responsibility of Business refers to the profitable service of client staff in an honorable and lawful manner. This definition includes the private vendor, making out that it is an important resource for the society and should treat customers ethically. Community investment in a socially responsible entrepreneurship, business requires knowledge of what social change is, how best to implement it (needs assessment, the definition of the idea, setting goals) so as to attain the maximum resolution, taking into account all facets of societal evolution. The most significant expression of socially responsible entrepreneurship is the duty to protect the surroundings. Responsible businesses for the conservation of natural resources use alternative, renewable energy sources, energy-saving technologies, as well as installations and technologies to restrict the spread of poisonous substances in nature, waste recycling, and other environmentally friendly production practices. This implies a positive contribution to society and managing the environmental impact of the initiative.

\section{SWOT ANALYSIS OF THE SOCIAL ENTREPRENEURSHIP IN BANGLADESH}

Bangladesh has emerged as an important destination for social business for the last couple of decades. Although it has some opportunities and also some problems. After analyzing aforesaid the data of social market (Grameen, BRAC and British Council [BD]) author has finalized the SWOT analysis of the Social entrepreneurship in Bangladesh. The SWOT analysis of Social entrepreneurship of Bangladesh is as follows: 
INTERNATIONAL JOURNAL OF ACADEMIC RESEARCH IN BUSINESS AND SOCIAL SCIENCES

Vol. 8, No. 11, Nov, 2018, E-ISSN: 2222-6990 @ 2018 HRMARS

\section{STRENGTHS}

Strengths behind the success of Social entrepreneurship of Bangladesh is the availability of low-cost labor force, labor availability for unemployment. FDI is legally permitted by the Government of Bangladesh, improved Generalized System of Preferences (GSP) advantages, an Excellent Telecommunications network, an advantage over currency against dollar/euro and special economic zone.

\section{WEAKNESSES}

Social entrepreneurship of Bangladesh also has some weakness like political instability, child labor, poor infrastructure, natural disaster, unavailability of nonstop power and gas, lack of marketing tactics, manufacturing machine isn't enough, lack of proper training for workers, and initiative with government is the lengthy process in Bangladesh.

\section{OPPORTUNITIES}

As a least developed country Bangladesh enjoys some specific advantages on FDI. Bangladesh is one of the most important members of (OBOR) initiative, Japan is very interested in the purchase of handloom textiles, home furniture and garments from Bangladesh. EU is willing to move from China to Bangladesh to establish big enterprises, so if anyone one to be the part of social entrepreneur not only within country, and also want to explore around globe, they have enormous opportunities to explore in the arena of social enterprise.

\section{THREATS}

Malaysia and Singapore have leading social business in our ASIA. They have a competitive advantage to attract and taking care of the foreign investment for social work and also they have the national interest in social business. We are behind of them for aforesaid reasons, also comparing to Bangladesh, Malaysia and Singapore has a better energy supply, infrastructural, transportation and communication systems, which is why they taking away some global opportunities from Bangladesh.

\section{FINDINGS}

In this paper, Social business emerges the competitive advantage of corporate social responsibilities, compare the social business with other business models, and appraise the social business scenario and how it can contribute to fulfilling of social need. Since the entrepreneurs in social business need to achieve social goals subject to no loss condition, they accept to face the challenges and the societal problems at the same time. Therefore, they must hold peculiar qualities in making a decision and dealing with risk and uncertain places. But the query is whether any such highly skilled person will be interested to extend the business without any individual gain. In social business, the owner who invests the fund is paid back only the original amount over a specific time period and he is not entitled to make any profit. But equally, there is no consideration of the time value of money the owner may tie down to bear the passing. Hence, we are saying, one can do profit-maximizing business and social business at the same time watching our new business model, people can make money from the traditional commercial enterprise, by CSR they can make changes and the same time promote social 
INTERNATIONAL JOURNAL OF ACADEMIC RESEARCH IN BUSINESS AND SOCIAL SCIENCES Vol. 8, No. 11, Nov, 2018, E-ISSN: 2222-6990 @ 2018 HRMARS

causes by solving the problem is to create a continuous contribution among unprivileged society. Simply, at that place is a big possibility of misuse of the social business as a promotional tool for the product market or experiment archiving tool for their profit-maximizing business. On the other hand, as investors have no individual interest, there might arise mismanagement on the role of entrepreneurs.

\section{CONCLUSION}

As we can see from the analysis above, in order to establish a good social enterprise, to enrich the social entrepreneurship landscape, all factors need to be taken into consideration. Social enterprises are not a type of enterprises that have their ultimate goal in making profits, but rather to realize social value through a business operation model, involves preparing a mental move from profit first to social impact. It produces new ideas and values on how businesses should relate to society, and how a business model should treat people and the community around us. This model and process not only for Bangladesh, but also for other countries in exchange with traditional business model to this integrated business model. We know social entrepreneurship is rapidly emerging on nationally and internationally. Businesses contribute to communities and society, producing goods and services that meet the needs of society. Investing in the social field by supporting initiatives in the field of education, education and solving social problems such as unemployment, poverty and homelessness. Malaysia and Singapore, they are leading social business in our ASIA. It's also, as with South Korea and Hong Kong, a really great place for women in startups. Referring to the aspects of public health, Donaldson et al (2011) analyze the reasons why social business represents an important area of consideration for public policy given the limits of traditional businesses. Bangladesh is one of the leading states to have varied examples of social entrepreneurship focusing on the preparation of basic education, health and other social need on demand for backward sectors of the population. While the social entrepreneurship is still evolving, this article has discussed about the business model, entrepreneurship, process and the impact of social entrepreneurship, even in Bangladesh. But as this platform is relatively not wide like traditional business, so it will take a few years to get back the practical result and long run output of social business by studies of effective social entrepreneurship.

Hence, this composition is an academic effort to contribute to the comprehension of social entrepreneurship as a process of evolution. It is obvious that augmenting similar studies will enable to develop social entrepreneurship and be significant for further promotion of social entrepreneurship. In this paper, the author used a new integrated business model approach as a main point for this paper to the implementation of social entrepreneurship/social business into traditional business looking at CSR. The justification behind the theme is to present meaningful and efficient business practice considering social development. Authors have shown the logical, sequential relationship between CSR and Social business same time in the traditional commercial enterprise, which will be a useful guide for entrepreneurs, and even same for existing business owners to be more creative and to produce an influential contribution to society. Innovation and opportunity seeking propensities are in common between commercial entrepreneurship and social entrepreneurship. What most of the researchers agree upon is the social intention of this orientation of entrepreneurship, which guides the mind towards social context. The other function of this theme is to offer a perspective of social entrepreneurship as a procedure that leads to social wealth, explores 
the chances for societal change and contributes to social ventures considering CSR into a traditional commercial enterprise. Every bit the mind of social business is not so fresh but was unprivileged staged. It may need some more time to assume a full-fledged and mature structure in both conceptual and functional dimensions. Seeing the huge demand of poverty alleviation and the position in which poverty exists, it can be stated that winning the war against poverty not only in Bangladesh, but also other countries requires innovative efforts and promotion of our novel business model and proper implementation into real business practice to assess the positive impact and contribute in a great scale by bringing change to society.

\section{LIMITATION}

Although the thought of social business has so far been able to draw ample attention of academicians, researchers as well as practitioners around the Earth, it has been open to criticism for some of its inherent restrictions. It would be rather difficult to answer being a human, someone may argue that why a person becoming an entrepreneur of social business out of only social passion, it can be viewed as an accident rather than a regular phenomenon. The primary object of the social business is to achieve social aims. Merely it is very difficult to quantify the functioning of a social business and impact on society. It is, in fact, difficult to measure such non-monetary achievement. Although the research has reached its aim, there was some unavoidable limitation. Firstly, we didn't explain in detail on the business operation process and project financing, it will be included in the next extension of this paper. Secondly, we mostly used secondary information, and own thought, it would be better if we had the chance to have a long time research on this issues, so there were time and research budgetary constraint for practical analysis. This is why rarely in some case result might be a bit affected on an application of this paper. Furthermore, the empirical study will be needed in the future. 
INTERNATIONAL JOURNAL OF ACADEMIC RESEARCH IN BUSINESS AND SOCIAL SCIENCES

Vol. 8, No. 11, Nov, 2018, E-ISSN: 2222-6990 (C) 2018 HRMARS

\section{REFERENCES}

Austin, J.E., Leonard, H., Reficco, E., \& Wei-Skillern, J. (2004). Corporate social entrepreneurship: A new vision of CSR. Harvard Business School Working Paper No. 05-021. Boston: Harvard Business School.

Azim, M., Ahmed, E., \& D’Netto, B. (2011). Corporate social disclosure in Bangladesh: A study of the financial sector. International Review of Business Research Papers, 7(2).

Carroll, A.B. 1991. The pyramid of corporate social responsibility: toward the moral management of organizational stakeholders. Business Horizons, pp. 39-48.

Danaher, G., Moriarity, B., \& Danaher, P. A. (2003). Social entrepreneurship and capacity building in linking Australian show people and regional and rural communities Queensland Journal of Educational Research, 19(2), 59-66.

Dees, J.G. \& Anderson, B.B. (2003). For-profit social ventures, International Journal of Entrepreneurship, Education (special issue on social entrepreneurship), 2, 1-26.

Dees, J.G. (1998). The meaning of "social entrepreneurship." Comments and suggestions contributed from the Social Entrepreneurship Founders Working Group. Durham, NC: Center for the Advancement of Social Entrepreneurship, Fuqua School of Business, Duke University. [Online] Available:

https://entrepreneurship.duke.edu/news-item/the-meaning-of-social-entrepreneurship/

Emerson, J. \& Twerksy, F. (Eds.). (1996, September). New social entrepreneurs: The success, challenge and lessons of non-profit enterprise creation. San Francisco: Roberts Foundation, Homeless Economic Development Fund.

Reis, T. (1999). Unleashing the new resources and entrepreneurship for the common good: A scan, synthesis and scenario for action. Battle Creek, MI: W.K. Kellogg Foundation, 27pp

Thompson, J. (2002). The world of the social entrepreneur. International journal of public sector management, 15(5), pp. 412-431.

Thompson, J.L., Alvy, G. \& Lees, A. (2000). Social entrepreneurship: A new look at the people and the potential. Management Decision 38(5) 328-338.

Vernon R. (1966). International Investment and International Trade in the Product Cycle. Product life cycle stage, [Online] Available:

https://www.toolshero.com/marketing/product-life-cycle-stages/ 
INTERNATIONAL JOURNAL OF ACADEMIC RESEARCH IN BUSINESS AND SOCIAL SCIENCES

Vol. 8, No. 11, Nov, 2018, E-ISSN: 2222-6990 @ 2018 HRMARS

Villeneuve-Smith, F. and Temple, N. (2015) State of Social Enterprise Survey 2015: Leading the world in social enterprise. Social Enterprise UK, [Online] Available:

https://www.bigsocietycapital.com/sites/default/files/attachments/State\%20of\%20Social\%

20Enterprise\%20Report\%202015.pdf

Yunus M. and B. Moingeon, and L. Lehmann- Ortega, "Building social business models: Lessons from the grameen experience," Long Range Planning, vol. 43, pp. 308-325, 2010.

Yunus M. (2011). Concept of Social Business. [Online]Available:

https://www.youtube.com/watch?v=NnPmotbt04\&list=LLPGEgJYsT2nbQhSnkNTvAlw

Yunus M., Jolis A. (1999), "Banker to the Poor", Bangladesh. ISBN 1-58648-198-3. 
INTERNATIONAL JOURNAL OF ACADEMIC RESEARCH IN BUSINESS AND SOCIAL SCIENCES Vol. 8, No. 11, Nov, 2018, E-ISSN: 2222-6990 @ 2018 HRMARS 